\title{
SERVICE BRAND IDENTITY STRATEGY AND MARKETING PERFORMANCE: AN EMPIRICAL EVIDENCE FROM TRAVEL AGENCY BUSINESSES IN THAILAND
}

\author{
Warawut Waranantakul, Mahasarakham Business School, Mahasarakham University, Thailand \\ Phapruke Ussahawanitchakit, Mahasarakham Business School, Mahasarakham University, Thailand \\ Pratanporn Jhundra-indra, Mahasarakham Business School, Mahasarakham University, Thailand
}

dx.doi.org/10.18374//JBS-13-4.1

\begin{abstract}
Service brand identity strategy has been viewed as a key success factor in performing under fluctuating business environments. Drawing on signaling theory, contingency theory, and structure-conduct-performance paradigm, the objective of this research is to investigate the relationships among service brand identity strategy and its consequences; long-term customer commitment, business image advantage, market reliability enhancement, and marketing performance. In addition, several antecedents are also examined; marketing leadership, market culture, resource readiness, and competitive forces as well as, the moderating effects of external communication capability and marketing learning capability. The results were derived from a survey of 103 travel agency firms in Thailand. The hypothesized relationships among variables are examined by using ordinary least square (OLS) regression analysis. Results suggest that employee expertise orientation has the most influence on long-term customer commitment and market reliability whereas, corporate visual establishment is a critical factor to increase business image relative to competitors. In addition, only market reliability enhancement is related to marketing performance. For antecedents, marketing leadership is an essential element for building service brand identity. Interestingly, external communication capability has the most explicit moderating role on corporate visual establishment and its consequences. Marketing learning capability did not play moderating role to yield the expected hypotheses. Moreover, theoretical and managerial contributions, a conclusion, and suggestions for future research are also discussed.
\end{abstract}

Keywords: Service Brand Identity Strategy, Long term Customer Commitment, Business Image Advantage, Market Reliability Enhancement, Marketing Leadership, Market Culture, Resource Readiness, Competitive Force, External Communication Capability, Marketing Learning Capability and Marketing Performance 